American University Washington College of Law

Digital Commons @ American University Washington College of Law

Articles in Law Reviews \& Other Academic Journals

Scholarship \& Research

2007

Beyond Schumpeter vs. Arrow: How Antitrust Fosters Innovation

Jonathan Baker

Follow this and additional works at: https://digitalcommons.wcl.american.edu/facsch_lawrev

Part of the Antitrust and Trade Regulation Commons, and the Law and Economics Commons 


\title{
BEYOND SCHUMPETER VS. ARROW: HOW ANTITRUST FOSTERS INNOVATION
}

\author{
JONATHAN B. BAKER*

\section{INTRODUCTION}

Antitrust enforcement surely keeps prices low and output high, but is it good for innovation? The question arises because the relationship between competition and innovation is the subject of a familiar controversy in economics. One view, often associated with Joseph Schumpeter, argues that monopolies favor innovation. An opposite view, often associated with Kenneth Arrow, argues that competition favors innovation. Taking their cue from this debate, some commentators qualify their support for antitrust policy, reserving judgment as to whether antitrust enforcement is good for innovation. ${ }^{1}$

\footnotetext{
* Professor of Law, Washington College of Law, American University. I am particularly indebted to Rich Gilbert, whose work inspired this essay and who provided extensive and insightful comments on an earlier draft. I am also grateful to Shane Greenstein for detailed and valuable comments, and to Mike Carrier, Joe Farrell, Jonathan Gleklen, Michael Katz, Josh Sarnoff, Howard Shelanski, and participants in the NBER 2007 Summer Institute program on Innovation Policy and the Economy for helpful discussions and comments. The views expressed are purely my own.

${ }^{1}$ E.g., Keith N. Hylton, Antitrust Law: Economic Theory and Common Law Evolution 20 (2003); SuZANne Scotchmer, InNovation and InCENTIVEs 173 (2004). See Michael L. Katz \& Howard A. Shelanski, Mergers and Innovation, 74 Antitrust L.J. 1, 3 (2007) ("In the light of the potential tension between competition and innovation, as in the light of the uncertainty that innovation creates for predictions about competitive effects of mergers and future conditions in the relevant markets, a growing body of commentary has questioned the relationship of antitrust law to innovation."); Jordi Gual, Time to Rethink Merger Policy? 3 Competition Pol'y Int'L 24, 43 (2007) (“[O]nce we consider competition in a dynamic setting. . . the link between increased rivalry . . . and welfare becomes less clear-cut than is commonly assumed."). Many of these commentators support antitrust enforcement in general, notwithstanding their uncertainty as to the best way of applying antitrust rules in innovation contexts. Other commentators recognize the economic debate but downplay its antitrust policy significance. See, e.g., 2A Phillip E. Areeda, Herbert Hovenkamp \& John L. Solow, Antitrust Law Il 407d (1995) (size and market power contribute to progressiveness (innovative activity); this relationship speaks against a ruthless atomistic structural policy but otherwise does not have important implications for antitrust policy); Richard Posner, Antitrust Law 20, 22 (2d ed. 2001) (monopoly is the source of significant social costs, although it cannot be condemned on the
}

74 Antitrust Law Journal No. 3 (2007). Copyright 2007 American Bar Association. Reproduced by permission. All rights reserved.This information or any portion thereof may not be copied or disseminated in any form or by any means or downloaded or stored in an electronic database or retrieval system without the express written consent of the American Bar Association. 
Such misgivings are unnecessary. As will be discussed below, the modern economic learning about the connection between competition and innovation helps clarify the types of firm conduct and industry settings where antitrust interventions are most likely to foster innovation. Measured against this standard, contemporary competition policy holds up well. On the whole, as will be shown, antitrust rules and enforcement today are appropriately focused to promote innovation. Specifically, as I describe in the second half of this essay, antitrust intervention can systematically promote innovation competition and pre-innovation product market competition, which will encourage innovation, without undermining those benefits by markedly increasing post-innovation product market competition and, thus, without tending to discourage innovation.

Underlying this entire discussion is a presumption that more innovation is good for society. It is worth pausing briefly on this point. From one generation to the next, innovation is undoubtedly a central determinant of the welfare of humankind. Economists studying individual projects, moreover, routinely find that the benefits of innovation to society as a whole greatly exceed the benefits to the firms that develop the innovation. ${ }^{2}$ Although excessive innovative effort is a theoretical possibility, ${ }^{3}$ it is safe to assume that broad regulatory policies promoting innovation are beneficial for society. Accordingly, when this essay explains why U.S. competition policy as practiced today-antitrust doctrines and enforcement priorities taken as a whole-fosters innovation, it is simultaneously providing an important reason why antitrust benefits society.

ground that the lack of price competition retards innovation); Massimo MotTA, ComPetition Policy: Theory and Practice 57 (2004) (Although "some intermediate levels of competition might be optimal for innovations and productive efficiency ... [t t he only sound and robust conclusion ... is that a monopoly (or a cartel) is worse than competitive market structures, because it fails to stimulate dynamic efficiency.").

${ }^{2}$ Edwin Mansfield, Microeconomics of Technological Innovation, in TECHNOLOGY AND Global Industry 311 (Bruce R. Guile \& Harvey Brooks eds., 1987); Jeffrey Bernstein \& M. Isaq Nadiri, Interindustry REDD Spillovers, Rates of Return, and Production in High-Tech Industries, 78 Am. Econ. Rev. 429 (1988); Zvi Griliches, The Search for REंD Spillovers, 94 Scandinavian J. Econ. S29 (Supp. 1992); Charles I. Jones \& John C. Williams, Measuring the Social Return to RE'D, 113 Q.J. Econ. 1119 (1998); cf. Timothy F. Bresnahan, The Mechanisms of Information Technology's Contribution to Economic Growth, in Institutions, InNovation and Growth: Selected Economic Papers 135-37 (Jean-Phillipe Touffut ed., 2003) (providing examples where the aggregate social returns to information technology investment exceed private returns because the inventor cannot easily contract with the many firms that benefit, including firms that make complementary products and co-inventors).

${ }^{3}$ In the theoretical models, excessive innovation may arise when the innovator profits mainly by diverting business from its rivals rather than by expanding the market. 


\section{COMPETITION AND INNOVATION}

Even a lemonade stand must respond to competition. If a nearby lemonade vendor cuts price, a lemonade seller that does nothing may lose too many of its customers to remain profitable. It may lower price to match; it may promise colder drinks; it may offer to vary the sweetness to match buyer tastes; it may add iced tea or cookies to its product line; it may play music to improve the ambiance. It must act to bring customers back.

Competition among firms indisputably creates powerful incentives for sellers to take steps to attract customers, most obviously by keeping prices low. A firm that does not reduce its price after a close rival cuts price risks losing its customers-so can be expected to lower price in response. Or the firm can attract buyers by making improvements in product attributes closely related to price and valued by consumers, like supplying more rapid delivery, offering higher product quality, offering more colors or styles or other additions to product variety, or providing additional post-sale services. Firms know that steps like these will help them sell more, so they may act first, stealing a march on their rivals by cutting costs and lowering prices or improving quality. The result of competition is, thus, cheaper and better products and greater production-to the immediate benefit of buyers but also, importantly, to the benefit of society as a whole. ${ }^{4}$ Competition is good because it leads firms to make more and better goods and sell them for less. ${ }^{5}$

\section{A. Schumpeter And Arrow}

While economists widely accept that competition encourages firms to improve product attributes closely related to price, economists have not been so quick to say that competition encourages innovation. When addressing whether competition fosters the development of new and different products, or new or improved production processes, the economics literature has historically been much more tentative.

\footnotetext{
${ }^{4}$ The social benefits of competition arise through the incentives that competition creates, as emphasized in this paragraph; through selection, as the best products and mostefficient producers tend to win out; and through R\&D spillovers, as will be discussed below.

${ }^{5}$ For example, an expert economist working for antitrust defendant IBM concluded that firms supplying electronic data processing during the 1960s and 1970s felt "constantly compelled by competition both to improve both their products and to reduce prices-and to react to the improved products and lower prices of competitors." Franklin M. Fisher, John J. McGowan \& Joen E. Greenwood, Folded, Spindled, and Mutilated: Economic Analysis and U.S. v. IBM 132 (1983).
} 
The argument for skepticism has its roots in the writing of Joseph Schumpeter, an Austrian native and Nazi refugee who taught at Harvard during the 1930s and 1940s. Schumpeter is most famous today for describing capitalism as developing though gales of "creative destruction," by which new technologies supplant the old. ${ }^{6}$ Schumpeter also is well known for suggesting that large firms and monopolists may be more innovative than firms in competitive markets. ${ }^{7}$ There are a number of possible reasons this could occur. Large firms might be better able than small ones to fund large research and development (R\&D) projects. It may be easier to explain to the suppliers of financial capital why R\&D projects have promise (overcoming agency problems and problems arising from information asymmetries) when the source of the financing is within the organization. Moreover, firms with a strong pre-existing market position, including monopolists, may be more willing to pursue $\mathrm{R} \& \mathrm{D}$ if, by virtue of their head start, they have less fear that rivals, lacking their installed base and reputation, would be able successfully to market products that emulate their new ideas or are produced using their improved processes. After all, the more that the returns to an innovation go to the firm that first develops the idea, the greater the incentive the firm will have to engage in $\mathrm{R} \& \mathrm{D}$ activity.

Another influential 20th century economist, Kenneth Arrow, emphasized a competing logic by which competition rather than monopoly promotes innovation. Arrow, a Nobel Prize-winning economist who has taught at Stanford and Harvard, explained in 1962 that a monopolist might innovate less than competitive firms because a monopolist has less to gain. ${ }^{8}$ A monopolist could spend a great deal of money to make a dramatic improvement - whether by lowering cost, improving quality, or creating a new product-only to find that it does not get much additional business because it already has most of the business there is to get. If a competitor had come up with the same innovation, by contrast, it would earn more because it would expect to take away much of the business previously conducted by rival firms. This limitation on the incentive of the monopolist to innovate is often termed the "Arrow effect" or the

\footnotetext{
${ }^{6}$ Joseph Schumpeter, Capitalism, Socialism, and Democracy 83 (3d ed. 1942).

7 See id. at 81-106; 1 Morton I. Kamien, Market Structure and Innovation RevisITED: JAPAN AND THE WORLd ECONOMY 331 (1989).

${ }^{8}$ Kenneth J. Arrow, Economic Welfare and the Allocation of Resources for Invention, in THE Rate and Direction of Economic Activities: Economic and Social Factors 609 (Richard Nelson ed., 1962). Put differently, Arrow observed that a monopolist bears a cost when innovating that an innovating competitor does not, as it gives up the opportunity to continue to earn monopoly profits without innovating. In consequence, the incremental gains from innovation to the monopolist may be less than those of a firm in a competitive setting that would expect to earn similar post-innovation profits.
} 
"replacement effect" (so-called because it arises to the extent the monopolist replaces itself rather than developing new business). It will likely be strongest when the new product or process can be expected to fully displace the old (a "drastic" innovation) and when the monopolist does not fear that some other firm (perhaps an entrant) will soon implement a similar new idea.

\section{B. Four Principles Relating Competition and Innovation}

The opposing arguments of Schumpeter and Arrow sparked an extensive economics literature seeking to relate innovation in an industry to the extent to which firms in the market compete. ${ }^{9}$ Through this later work, four important principles relating competition and innovation have emerged. These principles do not encompass every aspect of economic research on the determinants of innovation ${ }^{10}$ - far from it—but they do describe important aspects that are particularly relevant to antitrust.

First, competition in innovation itself - that is, competition among firms seeking to develop the same new product or process-encourages innovation. When firms see themselves in a tough race to innovate first, they try harder to win. This dynamic is particularly evident in the economic literature on R\&D competition in "patent races."

Second, competition among rivals producing an existing product encourages those firms to find ways to lower costs, improve quality, or develop better products. Firms engage in R\&D because innovation may allow them to escape competition, and so earn greater profits. This is one way of looking at Arrow's point: a firm that faces less pre-innovation competition and, thus, faces a more steeply downward-sloping demand curve, has a greater legacy flow of economic profits, which it has an incentive to pro-

\footnotetext{
${ }^{9}$ For a rich and thoughtful recent survey of the economic literature relating competition and innovation, which paints the research with a finer brush than I use here, see Richard Gilbert, Looking for Mr. Schumpeter: Where Are We in the Competition-Innovation Debate?, in 6 Innovation Policy and the Economy 159 (Adam B. Jaffe, Josh Lerner \& Scott Stern eds., 2006). Gilbert's nuanced literature review highlights, among other things, the significance of distinctions between product and process innovation, and between drastic and non-drastic innovation, that are not emphasized here.

${ }^{10}$ For example, the size of the expected reward to innovation also depends on factors other than the competition considerations outlined below, including the size of the innovation, the size of the market, and the extent to which innovating eliminates the innovator's profit from its pre-innovation technology. For a review of the empirical evidence relating firm size with R\&D intensity, see Richard J. Gilbert, Competition and Innovation, in aba Section of Antitrust Law, Issues in Competition Law and Policy (forthcoming 2008).
} 
tect by slowing its innovative effort. In other words, a firm that faces less competition has less need to work hard to escape competition. ${ }^{11}$

Third, firms that expect to face more product market competition after innovating have less incentive to invest in $R \mathcal{E} \mathcal{E}^{2} D$. This is the flip side of the previous principle: if innovation would not allow a firm to escape competition but would instead be expected to throw an innovating firm into a pool with sharks, the firm would anticipate profiting less from $\mathrm{R} \& \mathrm{D}$. In consequence, the firm would have less incentive to pursue innovations in the first place. ${ }^{12}$ This incentive may encourage firms introducing new products to seek to differentiate them from those of their rivals, as differentiated products often face less post-innovation product market competition than do products similar to those sold by other firms.

The widely accepted observation that the social returns to innovation exceed the private returns, remarked upon above, reflects that competition among producers ensures that buyers share in the social benefits of new ideas, so living standards rise. In the language of the software industry, this is a "feature" of competition, not a "bug." This observation does not imply that the key to more innovation is to allow firms to appropriate more of the social benefits of their new products and production processes, as through broadening intellectual property rights or relaxing post-innovation antitrust enforcement. Even in an industry in which innovators would expect to keep only a fraction of the benefits of their new ideas to society-perhaps because rival imitation would be rapid, brands are weak, first movers gain only limited benefits relative to

${ }^{11}$ The "escape competition" formulation is used in the modern economic growth literature. E.g., Philippe Aghion, Christopher Harris, Peter Howitt \& John Vickers, Competition, Imitation and Growth with Step-by-Step Innovation, 68 Rev. Econ. STud. 467, 468 n.4 (2001).

12 The inhibition to innovation arising from the prospect of post-innovation product market competition does not disappear if the potential innovator anticipates licensing its new product or production process rather than using it in production. If potential licensees expect to face product market competition when using the license, they would be expected not to compete aggressively to obtain the license and to pay less for it. Moreover, if the fear of product market competition with a dominant firm discourages potential rivals from purchasing the license, the only buyer may be the dominant firm, which may in consequence be able to drive a hard bargain with the innovator. For analysis of the complex interaction between the structure of the "market for ideas" (market for licensing innovations) and entrant incentives to innovate, highlighting conditions under which incumbent firms will engage in research more intensively than entrants, see Joshua S. Gans \& Scott Stern, The Product Market and the Market for "Ideas": Commercialization Strategies for Technology Entrepreneurs, 32 Res. PoL'y 333 (2003); Joshua S. Gans, David H. Hsu, \& Scott Stern, When Does Start-Up Innovation Spur the Gale of Creative Destruction? 33 RAND J. Econ. 571 (2002); Joshua S. Gans \& Scott Stern, Incumbency and REDD Incentives: Licensing the Gale of Creative Destruction, 9 J. Econ. \& Mgmt. Strategy 453 (2000). See also Ashish Arora, Andrea Fosfuri \& Alfonso Gambardella, Markets for Technology: The Economics of InNovation and Corporate Strategy (2001). 
followers, ${ }^{13}$ new ideas are rapidly and widely disseminated, or intellectual property protections are narrow-innovation incentives may be strong. ${ }^{14}$ This would occur if the incentive to escape current product market competition (the second economic principle) is more powerful than the fear of post-innovation product market competition (the third principle) in the decision-making calculus of potential innovators.

Fourth, a firm will have an extra incentive to innovate if in doing so it can discourage potential rivals from investing in RE्SD. This principle, the preemption incentive, is an important corollary of the third principle. The preemption incentive arises because an innovating firm may be able to benefit from its investments in R\&D not simply through its ability to offer buyers better or cheaper products, but also by discouraging potential rivals from innovating. While the initial innovator has the field to itself, an innovating rival would anticipate competition. By application of the third principle, the rival will have less incentive to invest in R\&D than the initial innovator. ${ }^{15}$

\footnotetext{
${ }^{13}$ First-mover advantages might arise, for example, if buyers come to associate the first mover with the product or if the first producer obtains cost savings from achieving greater scale or learns more rapidly.

${ }^{14}$ See, e.g. Kal Raustiala \& Christopher Sprigman, The Piracy Paradox: Innovation and Intellectual Property in Fashion Design, 92 VA. L. Rev. 1687 (2006); cf. Gregory Clark, A Farewell to Alms: A Brief Economic History of the World 233-37, 296-99 (2007) (the increased rate of innovation in Industrial Revolution England arose notwithstanding that innovators in leading sectors like cotton textiles appropriated little of the social benefits of their advances). If innovators would keep literally none of the benefits of innovation, they would have no incentive to invest in new products and processes. Under such circumstances, the third economic principle would be likely to have an overwhelming influence on firm incentives to (not) invest in R\&D. But the incentive to escape competition recognized in the second economic principle can be powerful and can strongly encourage innovation on balance, so long as there is some, albeit incomplete, appropriability.

15 The preemption incentive can also be understood as an application of the gametheoretic literature on strategic entry deterrence to R\&D competition. It is unlikely to be important if the incumbent firm faces product market competition, if the incumbent cannot easily close off all plausible innovation paths for rivals, or if an incumbent firm is not likely to come up with an innovation quickly even with a head start on R\&D. Gilbert, supra note 10 (manuscript at 23). Some empirical studies find evidence of firm innovation consistent with a preemption motive. E.g., Leemore S. Dafny, Games Hospitals Play: Entry Deterrence in Hospital Procedure Markets, 14 J. Econ. \& Mgmt. Strategy 513 (2005); Richard Blundell, Rachel Griffith \& John Van Reenen, Market Share, Market Value and Innovation in a Panel of British Manufacturing, 66 Rev. Econ. Stud. 529 (1999); Robert Smiley, Empirical Evidence on Strategic Entry Deterrence, 6 InT'L J. Indus. Org. 167 (1988). Moreover, John Sutton's wide-ranging demonstration that market concentration is related to the magnitude of sunk investments in R\&D by market participants can be interpreted as demonstrating the importance of the preemption incentive. John Sutton, Technology and Market Structure: Theory And History (1999). However, an empirical investigation of a related type of strategic entry deterrence, the possibility that incumbent firms strategically invest in excess capacity in advance of increases in demand to deter entry, concluded
} 
The preemption incentive arises in many contexts. For example, if a monopolist can make investments that effectively guarantee that it will quickly emulate any innovation introduced by a new entrant-perhaps by creating an extensive $\mathrm{R} \& \mathrm{D}$ operation along with a strong distribution network and brand reputation-those investments will discourage potential rivals from innovating in ways that compete with the monopolist without reducing the monopolist's own incentives to innovate. ${ }^{16} \mathrm{Or}$ if a monopolist can use a new product innovation to discriminate in price (by sorting buyers between its existing product and the new one according to their willingness to pay), but a new entrant making the same new product innovation would find itself competing with the former monopolist, the monopolist may expect to earn more from the new product than the entrant would, and consequently have a greater incentive to conduct R\&D to develop it. ${ }^{17}$ Similarly, a monopolist has a greater incentive than a firm facing competition to develop improved production process technologies when the innovator is unable to use intellectual property rights to exclude its rivals. ${ }^{18}$

The interplay of the second and third principles is illustrated by events in the U.S. automobile industry during the 1970s. As I have explained more fully elsewhere, the second principle helps explain why Nissan and Toyota aggressively innovated in small cars during that decade, while the Big Three U.S. automakers did not. ${ }^{19}$ In the large U.S.

that in the industry studied (chemicals), such behavior was rare. Marvin B. Lieberman, Excess Capacity as a Barrier to Entry: An Empirical Appraisal, 35, J. Indus. Econ. 607 (1987).

${ }^{16}$ See Richard Gilbert \& David Newbery, Preemptive Patenting and the Persistence of Monopoly, 72 Am. Econ. Rev. 514 (1982). But if the dominant firm views such investments as too costly and risky, it may instead choose to take short-term profits and allow its market position to erode with rival entry. See Jennifer Reinganum, Uncertain Innovation and the Persistence of Monopoly, 73 Am. Econ. Rev. 741 (1983). This latter dynamic may describe, for example, how Nintendo acted in its competition with Sega to develop and market video games. See Adam M. Brandenberger \& Barry J. Nalebuff, Co-opetition 237-41 (1996).

${ }_{17}$ See Shane Greenstein \& Garey Ramey, Market Structure, Innovation and Vertical Product Differentiation, 16 INT'L J. Indus. ORG. 285 (1998) (highlighting monopolist's disincentive to license an innovation when it expects to face post-licensing competition from a competitive fringe of suppliers of the older generation product; absent such competition, the monopolist would price the old and new products to maximize joint profits, recognizing the extent of differentiation between them).

${ }^{18}$ Cf. Partha Dasgupta \& Joseph Stiglitz, Industrial Structure and the Nature of Innovative Activity, 90 Econ. J. 266 (1980) (presenting a model of process innovation in a Cournot oligopoly with free entry in which, among other things, cost reduction is greater in industries characterized by a higher degree of monopoly power).

${ }^{19}$ See generally Jonathan B. Baker, Fringe Firms and Incentives to Innovate, 63 AnTitrust L.J. 621 (1995). Nissan and Toyota's success did not derive from a common, distinctively Japanese innovation in the production process. Although both Nissan and Toyota found ways to improve quality and lower price more rapidly than their rivals during the 1970s, they did not innovate in the same way. Toyota is famous for developing and implement- 
market, Nissan and Toyota saw themselves as little fish in a very competitive pond; their best way to escape competition was to make better and cheaper cars. By contrast, the leading U.S. firms were not aggressively competing, and, in particular, were not competing hard in small cars, where profits were low. So their motive to escape competition was weak. If the Japanese firms had instead thought that the Big Three would fight back more vigorously, with stronger efforts to improve their small car products and their production processes, the outcome might have been different. Then, as the third principle suggests, Nissan and Toyota, foreseeing stronger post-innovation competition, might not have been so eager to invest in improving their small cars.

\section{Empirical Studies Relating Competition and Innovation}

These four economic principles help explain R\&D investment and productivity growth in a wide range of industries. Economists studying the effects of competition on innovation empirically originally attacked the problem by looking for similarities across innovative industries and for differences between more and less innovative ones. At one time, empirical economists had created a cottage industry relating market concentration in an industry (thought of as a proxy for product market competition) to R\&D expenditures in the same industry (thought of as a proxy for innovation). Many found what was termed the "inverted U": innovation was greatest not in industries with a competitive market structure, but in those industries with oligopolistic market structures (a handful of firms, but more than a single producer)..$^{20}$

On its face, this result tended to suggest that the markets most congenial to innovation were less than fully competitive (albeit not monopolies either). But these studies were unconvincing. ${ }^{21}$ The link between

ing production process innovations that include short production cycles, small production lots, and the just-in-time inventory system. By contrast, Nissan improved quality and lowered cost and price just as rapidly while organizing production as the Big Three did, with long production runs. Nissan improved the approach to production employed by the U.S. automakers by adopting inventory and quality control methods, such as computerized scheduling and total quality control, known to the Big Three but not implemented by them.

${ }^{20}$ For a survey, see William L. Baldwin \& John T. Scott, Market Structure and Technological Change 63-113 (1987).

${ }^{21}$ See generally Wesley Cohen, Empirical Studies of Innovative Activity, in HandBoOK oF the Economics of Innovation and Technological Change 182, 191-98 (Paul Stoneman ed., 1995); Wesley M. Cohen \& Richard C. Levin, Empirical Studies of Innovation and Market Structure, in 2 Handbook of Industrial Organization 1059, 1074-79 (Richard Schmalensee \& Robert D. Willig eds., 1989); P.A. Geroski, Innovation, Technological Opportunity, and Market Structure, 42 OXford Econ. PApers 586 (1990); Richard C. Levin, Wesley M. Cohen \& David C. Mowery, RE'D Appropriability, Opportunity and Market Structure: New Evidence on Some Schumpeterian Hypotheses, 75 Am. Econ. Rev. 20 (Papers \& Pro- 
measured concentration and competition was weak, as was the link between R\&D expenditures and innovation. The gravest difficulty was in isolating the effect of competition. One industry might be particularly innovative for a number of reasons other than the extent of pre-innovation competition. Technological opportunities may be great: scientists and engineers may see ways to improve computer chips but not ways to improve potato chips. Or firms may have greater guarantees they will be free from post-innovation competition, for example, because they expect broad intellectual property protections or because their prior success gives them an advantage in keeping customers. It turned out to be virtually impossible to separate out possibilities like these from differences in the extent of competition when comparing one industry with another, so researchers could not practically exploit cross-industry comparisons to tell whether and how competition mattered. ${ }^{22}$

Recently, several economists motivated by concerns among researchers working in the field of economic growth have made a heroic effort to address many of the problems with the earlier cross-industry studies and, in doing so, appear to have resurrected the "inverted U" result..23 But the modern studies still do not control satisfactorily for differences across industries in the extent and rate of growth of technological opportunity and in the conditions of appropriability. ${ }^{24}$ In any case, one of

ceedings May 1985). A related project of empirical economists of the same era, comparing profits or prices in an industry to market concentration, also conducted through cross-industry comparisons, was equally unsuccessful.

${ }_{22}$ Moreover, a weak positive relationship between R\&D intensity and concentration would be expected to appear simply because fewer firms can profitably "fit" in markets in which firms have high fixed costs resulting from R\&D competition. SutTon, supra note 15 , at 474 .

${ }^{23}$ Philippe Aghion, Nick Bloom, Richard Blundell, Rachel Griffith \& Peter Howitt, Competition and Innovation: An Inverted U Relationship, 120 Q.J. Econ. 701 (2005). See PHIlippe Aghion \& Rachel Griffith, Competition and Growth: Reconciling Theory and EVIDENCE (2005).

${ }^{24}$ In particular, the studies cited in the previous footnote are only able to control for industry effects in two-digit SIC industries, which are so broad as to be little better than no controls at all. Cf. Katz \& Shelanski, supra note 1, at 22-23 (questioning implications of this line of research for merger policy). Another cross-industry study relating competition and innovation in British manufacturing by some of the same authors, Blundell, Griffith \& Van Reenen, supra note 15, adopts a different strategy for controlling for industry effects. It does so indirectly, by using information on prior rates of innovation by each firm as a proxy for a range of factors that would influence that firm's incentives to invest in R\&D (which presumably include industry-wide effects as well as firm-specific ones). This study finds evidence that less-competitive industries innovate less (consistent with the second principle) and that firms with a high market share have greater incentives to innovate preemptively (consistent with the fourth principle). The results are notable given that the study would be expected to be biased against finding any relationship, as industry concentration and firm market share are poorly measured. (Product markets are defined at broad three-digit industrial classification levels and geographic markets are presumed U.K.-wide without analysis.) Another study, a cross-sectional analysis using firm-level data, 
the authors interprets this line of research as showing that in general, for the industries studied, "a strengthening of competition policy is likely to have a positive overall effect on innovation," in contradiction to Schumpeterian theories. ${ }^{25}$

An alternative strategy for studying the empirical relationship between competition and innovation discards the cross-industry study and instead compares the performance of the same industry across countries. ${ }^{26}$ By limiting attention to a single industry, studies adopting this approach avoid the need to control for differences across industries in the extent and rate of growth of technological opportunity and in the conditions of appropriability. ${ }^{27}$ For example, the tobacco industries in the United States and the United Kingdom were both monopolies around the start of the 20th century, but during different decades. Although both had access to the same technologies for production improvements, technological innovation was more rapid for each during competitive periods. ${ }^{28}$ More broadly, leading business consultantsMichael Porter, and a team from the McKinsey Global Institute-have

finds evidence that competition (as measured by more than five rivals or lower profit margins) is associated with greater rates of total factor productivity growth for individual firms. Stephen J. Nickell, Competition and Corporate Performance, 104 J. PoL. Econ. 724 (1996).

${ }^{25}$ Peter Howitt, Endogenous Growth, Productivity and Economic Policy: A Progress Report, 8 Int'l Productivity Monitor 3, 10 (2004). See also Peter Howitt, Innovation, Competition and Growth: A Schumpeterian Perspective on Canada's Economy 1 (C.D. Howe Institute Commentary, No. 246, April 2007) ("Competition policy should not be relaxed in hopes of boosting innovation, because more competition actually strengthens the incentive to innovate.").

26 The success of this empirical strategy in controlling for cross-industry differences, to isolate the effect of competition on innovation, depends importantly on how well industries are defined. Still another empirical approach looks at the effect of entry or merger on R\&D. But this literature has not yet yielded strong conclusions, according to Michael Katz and Howard Shelanski, and will not be discussed further here. Katz \& Shelanski, supra note 1, at 23-27.

${ }^{27}$ Both empirical strategies were followed by John Sutton in his influential study of the relationship between R\&D and market structure. SutTon, supra note 15. Sutton argued that market structure should be related to a parameter reflecting the extent to which a firm that outspends its rivals on R\&D can thereby raise buyers' willingness to pay for its products in comparison with those of its rivals. This "escalation parameter" depends on seller technology, the extent of product differentiation, and buyer tastes. In particular, if the escalation parameter is large, the leading firm in the market will spend heavily on R\&D relative to its sales and achieve a larger market share. But if the escalation parameter is small, a range of market structures is possible. Sutton supported his theory first by analyzing statistically a cross-industry data set and second, through an informal narrative analysis of the relationship between $\mathrm{R} \& \mathrm{D}$ and observable features of market structure in selected industries across a number of nations. He cautioned that the value of his crosscountry comparisons was limited by the fact that the R\&D-intensive industries he studied were "essentially global." Id. at 480 .

${ }^{28}$ Eric W. Zitzewitz, Competition and Long-Run Productivity Growth in the U.K. and U.S. Tobacco Industries, 1979-1939, 51 J. Indus. ECON. 1 (2003). 
independently found that in one important industry after another, including both manufacturing and services, greater product market competition among firms within a nation leads to higher productivity for firms in that country. ${ }^{29}$

It is possible that these results mistakenly attribute to differences in competition effects that are actually due to other important differences across nations affecting firm incentives to innovate (differences in national culture or the political power of various industries, perhaps). This does not seem very likely, however, given that the more innovative industries (and the more competitive ones) are sometimes found in one country and at other times found in another. Moreover, this possibility is inconsistent with empirical studies that document productivity gains in those individual industries within a nation that have grown more competitive over time for reasons (such as increased import competition) unconnected with the past performance of the specific industry under study. ${ }^{30}$

29 See William W. Lewis, The Power of Productivity: Wealth, Poverty, and the Threat to Global Stability (2004) (survey of studies conducted by the McKinsey Global Institute); Michael Porter, The Competitive Advantage of Nations (1990); see also Chad Syverson, Market Structure and Productivity: A Concrete Example, 112 J. PoL. Econ. 1181 (2004) (concrete producers in more competitive localized markets experienced higher average productivity, mainly because inefficient producers exited); $c f$. Eric Bartelsman, John Haltiwanger \& Stefano Scarpetta, Microeconomic Evidence of Creative Destruction in Industrial and Developing Countries (Working Paper Oct. 2004), available at http://www.econ. umd.edu/ haltiwan/Creative_destruction_BHS.pdf (surveying sources of productivity gains). These studies might be expected to be biased against finding an effect, to the extent that firms in industries with less-competitive market structures are induced by their nation's competition policy to behave as though they faced more competition. See Irwin Stelzer, Coping with Market Power in the Modern Era 10 (Hudson Institute White Paper, Spring 2007), available at http://www.hudson.org/files/publications/StelzerWhitePaper March07.pdf. At the level of national aggregates, moreover, faster productivity growth appears to be associated with more effective competition policy enforcement. See Mark Dutz \& Aydin Hayri, Does More Intense Competition Lead to Higher Growth? (World Bank Policy Research Working Paper No. 2320, Nov. 30, 1999), available at http://ssrn.com/ abstract=630693; Stefan Voigt, The Economic Effects of Competition Policy-Cross-Country Evidence Using Four New Indicators (Sept. 2006), available at http://ssrn.com/abstract=925794; see generally OECD, Directorate for Financial and ENTERPrise AfFairs, Competition Committee, Relationship Between Competition Policy and Economic Performance (2007), available at http://lawprofessors.typepad.com/antitrustprof_blog/files/comp_ econ_perf_8_feb_2007.pdf (survey of literature relating competition policy to output growth, productivity, productivity growth and employment); but cf. Keith N. Hylton \& Fei Deng, Antitrust Around the World: An Empirical Analysis of the Scope of Competition Laws and Their Effects, 74 ANTITRUST L.J. 271 (2007) (unable to identify confidently a relationship between the scope of a nation's competition laws or their enforcement and the intensity of competition).

30 See James M. MacDonald, Does Import Competition Force Efficient Production?, 76 Rev. Econ. Stat. 721 (1994); José E. Galdón-Sánchez \& James A. Schmitz Jr., Competitive Pressure and Labor Productivity: World Iron-Ore Markets in the 1980's, 92 Am. Econ. Rev. 1222 (2002). For a general survey of what can be learned about productivity from following 


\section{Competition as a Motive for Innovation}

Taken as a whole, this empirical evidence highlights the importance of the second principle. As a general rule, competition does not just lead firms to produce more and charge less; it encourages them to innovate as well. ${ }^{31}$ Competition supplies a powerful motive for innovation. ${ }^{32}$ The immediate beneficiaries are typically the innovating firms themselves, which profit from product and process improvements, and their buyers, who can purchase better or cheaper products. The indirect beneficiaries include other firms, which can observe, emulate, and improve

individual firms over time, see Eric J. Bartelsman \& Mark Doms, Understanding Productivity: Lessons from Longitudinal Microdata, 38 J. EcON. Lit. 569 (2000).

31 The competitive incentive to innovate plays out on the ground through the role of entrepreneurs, viewed broadly. Competition requires, breeds, and rewards those who see opportunities and take steps to make their vision happen. Those steps are often fraught with risk, while simultaneously pregnant with the potential for gain. In the hypothetical lemonade stand example, innovation could take place in a range of activities, including the production process (squeezing lemons); product design (raspberry-flavored lemonade); marketing (creating a brand name); distribution (adding more sidewalk locations, or convincing a local coffee shop chain to place the lemonade stand's products on its menu); or finance (extending microcredit borrowing opportunities to ten-year-olds). The entrepreneurs developing and implementing new ideas could be located within an existing business, where a wide range of employees, including workers as well as managers, may play the entrepreneurial role, or outside an existing business; in the latter case, the risks and rewards are likely greater. Entrepreneurs often must convince co-workers, lenders, customers, and suppliers that risks are worth taking; this is a task that may require salesmanship and coordination. One point of the Toyota production system was to encourage workers to act as entrepreneurs in identifying ways of improving the production process, and one point of business education is to train executives in identifying and implementing entrepreneurial opportunities to innovate. But it is an open question in the economics literature how best to organize the firm internally to provide optimal incentives for entrepreneurial activity, managerial effort, and worker effort. See Nickell, supra note 24, at 725-28 (surveying literature on effects of competition on performance of agents within firms).

32 Within the framework of calibrated economic growth models, the adverse effect on productivity that arises when firms can prevent their competitors from using knowledge spillovers to improve production processes and product designs has been recognized by Stephen Parente and Edward Prescott. They conclude that differences in living standards across nations emerge largely as a result of competition-reducing policies within less-developed countries, put into place to protect the interests of groups that benefit from current ways of production, which prevent firms from adopting better production methods. Stephen L. Parente \& Edward C. Prescott, Barriers to Riches (2000). 
on those innovations, ${ }^{33}$ creating more direct benefits to buyers, more indirect benefits to other firms, and so on. ${ }^{34}$

To the firm, innovation is like solving a puzzle. Before introducing lemonade from freshly squeezed lemons, a lemonade stand will evaluate the profit potential. It will investigate buyer preferences, gauging how many buyers would find the new product attractive, how much they would likely pay, and the costs and benefits of advertising. It will evaluate production costs, the expense of adopting alternative production processes, the likely cost savings from learning or producing at scale, and the costs and benefits of more $\mathrm{R} \& \mathrm{D}$. It will assess the likely responses of rivals, and it will consider what happens if they innovate and it does not. Many pieces must fall into place before a new lemonade product appears in the market. Competition is not a piece of the puzzle; it is the spark that leads a lemonade stand to open the puzzle box and make the effort to solve it. And every innovation puzzle that one firm solves helps it, and other firms, identify and solve other puzzles.

\section{ANTITRUST AND INNOVATION}

It might appear that these economics principles do not take antitrust policy beyond the competing perspectives of Schumpeter and Arrow. After all, the second and third economic principles would seem to point in opposite directions with respect to promoting product market competition. Greater product market competition, as would result from antitrust enforcement, would seem to encourage innovation directly, through application of the second principle. But it would simultaneously seem to discourage innovation indirectly, through application of the third principle, as prospective innovators come to worry that they will not fully benefit from their new ideas. ${ }^{35}$ This line of thinking would

\footnotetext{
${ }^{33}$ If a lemonade stand develops a better way of squeezing lemons, rival lemonade stands might improve upon the new approach, firms in other industries using fresh fruit (producers of frozen juice concentrate, perhaps) might adopt its new process, and firms that produce the equipment used in juice-squeezing might develop modifications to their equipment to make squeezing less costly or more rapid. The lemonade stand itself may, on its own or working with suppliers and customers, see ways of making its process improvement even better. Any of these firms might further recognize that a new lemonsqueezing process makes possible a new and better form of business organization, such as creating a centralized squeezing operation to service all lemonade stands in the area.

${ }^{34}$ The economy-wide benefits of these spillovers are emphasized in the endogenous growth literature. For a non-technical survey and guide to the literature, see generally Elhanan Helpman, The Mystery of Economic Growth (2004).

${ }^{35}$ If incentives for preemptive innovation are important, moreover, they might lead a dominant incumbent to innovate more and rival entrants to innovate less (applying the fourth principle).
} 
suggest continuing to reserve judgment as to whether antitrust enforcement is good for innovation.

This reasoning misleads because antitrust is not a general-purpose competition intensifier. Rather, antitrust intervention can be focused on industry settings and categories of behavior where enforcement can promote innovation. ${ }^{36}$ The modern economic understanding about the relationship between competition and innovation goes beyond Schumpeter and Arrow by suggesting ways for antitrust rules and enforcement efforts to target types of industries and types of conduct. Through such selection, antitrust intervention can systematically promote innovation competition and pre-innovation product market competition, which will encourage innovation, without markedly increasing post-innovation product market competition, and, thus, without detracting from the pro-innovation benefits. ${ }^{37}$ Indeed, as will be demonstrated, current U.S. antitrust rules and enforcement priorities are on the whole well-targeted to foster innovation. ${ }^{38}$

\footnotetext{
36 The institutional design problem for policy makers can be framed in terms of the optimal provision of public goods. On the one hand, information is a public good. Absent property rights, private firms will underinvest in developing and implementing new products and production processes (consistent with the third principle). On the other hand, competition is a public good too. When it is lacking in innovation markets (first principle) or product markets (second principle), private firms will also underinvest in innovation. From this perspective, antitrust rules can be thought of as one way of tailoring the breadth and scope of property rights to assure the optimal mix of the two types of public goods. Cf. Daron Acemoglu \& Ufuk Akcigit, State-Dependent Intellectual Property Rights Policy (MIT Working Paper No. 06-34, 2006), available at http://ssrn.com/abstract $=951788$ (providing model of innovation incentives in which the optimal intellectual property regime is least protective when product market competition is strong); Mark A. Lemley, $A$ New Balance Between IP and Antitrust, 8 Sw. J.L. \& Trade Am. 237 (2007) (arguing that when intellectual property rights are strong, antitrust enforcement should be strong as well).

${ }^{37}$ Cf. Ilya Segal \& Michael Whinston, Antitrust in Innovative Industries (NBER Working Paper No. 11525, 2005), available at http://ssrn.com/abstract=776013 (identifying settings in which a more protective antitrust policy raises the rate of innovation); Michael A. Carrier, Two Puzzles Resolved: Of the Schumpeter-Arrow Stalemate and Pharmaceutical Innovation Markets 5 (2006) (unpublished manuscript) ("[T] he absence of process innovation and presence of high appropriability and technological opportunity demonstrate the superiority of competition in bringing about pharmaceutical innovation.").

38 The problem of devising policies that promote innovation by enhancing innovation competition and pre-innovation product market competition (the first and second economic principles), without simultaneously discouraging innovation by fostering post-innovation competition (the third economic principle), also arises in the design of rules and procedures for intellectual property rights enforcement. Broader and longer intellectual property rights implement the idea of the third economic principle-reducing postinnovation product market competition to increase the incentives for innovation. But once those intellectual property rights are granted, incentives for further innovation are reduced through the operation of the second principle, as pre-innovation product market competition going forward may be lessened. Initial innovation may be encouraged, but successive (sequential) innovation discouraged. Because much innovation is successive,
} 


\section{A. Evaluating Whether Antitrust Fosters Innovation}

Demonstrating that antitrust rules and enforcement foster innovation raises a methodological problem. It would be nice to evaluate the argument of this essay with case studies examining whether and when specific instances of antitrust intervention encouraged innovation in the industry where they took place. ${ }^{39}$ That kind of retrospective is made difficult, however, by the problems understanding likely industry evolution with respect to R\&D but for the antitrust intervention. Suppose, for example, the Federal Trade Commission sought to evaluate whether its late-1990s monopolization case against Intel enhanced innovation in microprocessors. ${ }^{40}$ In that case, the FTC alleged that Intel had diminished the incentives of Intel customers generally to innovate in microprocessor technology by refusing to deal with three customers (Compaq, Digital Equipment Corp., and Intergraph) that were also rivals of Intel. The FTC alleged that Intel cut off the firms' access to technical information about upcoming Intel microprocessor products that the customers needed to design complementary products like personal computers, as a means of gaining bargaining leverage in unrelated commercial disputes involving the scope of competing intellectual property rights. The "natural and probable effect of Intel's conduct," according to the FTC's complaint, was to reduce the incentives of those three firms and other firms that were Intel customers or otherwise commercially dependent upon Intel to develop new technologies relating to microprocessors. Intel defended itself by denying that the conduct al-

building on and improving what has gone before, it is possible that broader and longer intellectual property rights can on balance reduce incentives to innovate. See generally Robert Merges \& Richard R. Nelson, On Limiting or Encouraging Rivalry in Technical Progress: The Effect of Patent-Scope Decisions, 25 J. Econ. Behavior \& Org. 1 (1994); Scotchmer, supra note 1 at 127-59. Critics of current intellectual property enforcement have suggested revisions to patent rules and procedures intended, in part, to reduce the likelihood that they would reduce post-innovation competition and successive innovation. FeD. Trade Comm'n, To Promote Innovation: The Proper Balance of Competition and Patent Law and Policy (2003), available at http://www.ftc.gov/opa/2003/10/cpreport .htm; A Patent System for the 21st Century (Stephen A. Merrill, Richard C. Levin, \& Mark B. Myers eds., 2005) (Nat'l Academy of Sciences report); Adam B. Jaffe \& Josh Lerner, Innovation and its Discontents: How Our Broken Patent System Is Endangering Innovation and Progress, and What to Do About It (2004).

${ }^{39} \mathrm{~A}$ full accounting would also require analysis of the deterrent effect of enforcement on the conduct of firms in all other industries, see generally, Jonathan B. Baker, The Case for Antitrust Enforcement, 17 J. Econ. Persp., Fall 2003, at 27, and an analysis of the consequences for innovation of non-enforcement decisions.

40 This administrative case was brought in 1998, when I was Director of the Bureau of Economics, and settled in 1999, after I had left the FTC. Intel Corp., FTC Dockett. No. 9288 (June 8, 1998) (Complaint); Intel Corp., FTC Dockett. No. 9288 (Mar. 17, 1999) (Agreement Containing Consent Order). These documents are available at http://www. ftc.gov/alj/D9288/index.htm. 
leged in the complaint diminished the incentives of any firm to develop new innovations of any kind. The settlement prohibited Intel from impeding customer access to technical information for reasons related to an intellectual property dispute or basing its microprocessor supply decisions on the existence of such a dispute.

The FTC presumably expected that this settlement would encourage rival innovation to take on Intel in microprocessors without markedly discouraging Intel's own innovation, so that innovation was promoted in the industry as a whole. It is not easy to tell whether that in fact happened. Intel has continued to innovate in microprocessors, and Intel's most important rival, AMD, a much smaller firm, has developed new products as well. But these observations, however suggestive, do not setthe the issue. To determine the effects of the settlement on innovation rigorously, it would be necessary to identify the likely evolution of the microprocessor industry absent the settlement and to determine whether AMD and Intel would have innovated as rapidly and in the same way there. This would be a difficult task. ${ }^{41}$

Most retrospective efforts instead examine whether the case and the relief obtained are consistent with a reasonable theory of how antitrust enforcement would increase innovation, grounded in economic analysis and industry facts, and then look at the subsequent industry evolution to see whether firms undertook vigorous innovative efforts..$^{42}$ The latter approach is most convincing as a way of gauging the effect of antitrust cases on industry innovation when it is possible to identify changes or differences in innovation strategies among firms following the enforce-

\footnotetext{
${ }^{41}$ One possible approach would require compulsory process, which the FTC is permitted to employ for this kind of study pursuant to Section $6(\mathrm{~b})$ of the FTC Act, 15 U.S.C. $\S 46$ (b). The FTC could review the R\&D and marketing plans of Intel, AMD, and other industry participants, before and after the complaint and settlement (assuming those old documents are still available), and depose key executives, in order to determine whether Intel and its rivals changed how they thought about innovation as a result of the settlement.

${ }^{42}$ For examples involving the FTC's Intel case, see Carl Shapiro, Technology Cross-Licensing Practices: FTC v. Intel (1999), in The Antitrust Revolution: Economics, CompetiTION, And Policy 350 (John E. Kwoka, Jr. \& Lawrence J. White eds., 4th ed. 2004); Richard J. Gilbert \& Willard K. Tom, Is Innovation King at the Antitrust Agencies? The Intellectual Property Guidelines Five Years Later, 69 Antrtrust L.J. 43, 66-74 (2001); Randal C. Picker, Regulating Network Industries: A Look at Intel, 23 Harv. J.L. \& Pub. PoL'y 159 (1999). For examples involving other cases, see F.M. Scherer, Technological Innovation and Antitrust (American Antitrust Institute Working Paper 05-07, 2005), available at http://www.anti trustinstitute.org/archives/files/431.pdf (reviewing the history of seven major U.S. monopolization cases in high-technology fields). Scherer concludes, among other things, that "dominant firms have accumulated far more monopoly power than is necessary to motivate and sustain the most rapid and beneficial rate of technological progress," but that courts often take "far too long . . . to come to grips with the problem." Id. at 62-63.
} 
ment action and tie that variation to changing incentives created by the antitrust case. ${ }^{43}$

The remainder of this essay will evaluate the effects of antitrust policy on innovation in a different way: by examining whether antitrust enforcement is targeted at industries and practices that have particular promise for promoting innovation, given the four economic principles set forth above. The focus will be on the kind of industries and practices where enforcement is concentrated, rather than on specific outcomes in individual cases. ${ }^{44}$

\section{B. Protecting Innovation and Technology Competition}

An antitrust policy aimed at fostering innovation would challenge practices that directly reduce innovation competition regardless of industry. This is an application of the first economic principle. In particular, antitrust enforcement can protect competition in innovation and technology markets in several ways.

First, antitrust fosters innovation by attacking agreements among innovation rivals not to conduct $\mathrm{R} \& \mathrm{D}$, undertaken with no legitimate justification. ${ }^{45}$ In addition, antitrust promotes innovation by challenging horizontal mergers that reduce the number of likely innovators when there are few, absent countervailing innovation efficiencies. ${ }^{46}$ Third, antitrust challenges to conduct that raises the transactions costs to firms of participating in standard setting encourages innovation by discouraging

${ }^{43}$ E.g., Timothy F. Bresnahan, Post-Entry Competition in the Plain Paper Copier Market, 75 Am. Econ. Rev. 15 (1985) (Papers and Proceedings) (describing how 1975 FTC consent decree with Xerox fostered innovation in the plain paper copier industry). Bresnahan identified the effect of that settlement on innovation by analyzing differences in the process and product improvements developed by the incumbent firm and new entrants after the settlement. He found that firms innovated in different ways, reflecting differences in their resources and market position, consistent with what would be predicted by economic theory. This research strategy would be more difficult to employ in the Intel example because fewer firms were involved.

44 This approach to evaluating the innovation effects of antitrust policy puts aside concerns that antitrust enforcement may be ineffective because the legal machinery operates slowly relative to the pace of change in many high-tech markets, on the view that the benefits of antitrust enforcement for innovation arise primarily from deterring anticompetitive conduct throughout the economy rather than from simply remedying competitive problems in the specific contexts where those problems arise.

${ }^{45}$ United States v. Auto. Mfrs. Ass'n, 307 F. Supp. 617 (C.D. Cal. 1969) (consent decree settling allegations of conspiracy to suppress automotive pollution control R\&D).

${ }^{46}$ See generally Richard J. Gilbert \& Steven C. Sunshine, Incorporating Dynamic Efficiency Concerns in Merger Analysis: The Use of Innovation Markets, 63 AnTitrust L.J. 569 (1995); Katz \& Shelanski, supra note 1, at 41-44; Carrier, supra note 37, at 40-63 (evaluating FTC pharmaceutical innovation market merger challenges). This statement is not a tautology because it incorporates a presumption that with fewer innovators, aggregate innovative effort will decline. 
conduct that would make new product development costlier for all. ${ }^{47}$ Innovation competition can also be promoted by antitrust challenges to restraints on competition in technology markets, ${ }^{48}$ particularly dominant firm conduct that makes it more difficult for small innovative firms to commercialize their own products or sell out to a large incumbent. ${ }^{49}$

\section{Protecting Product Market Competition: Types of Industries}

An antitrust policy aimed at fostering innovation would target enforcement efforts at product markets as well as innovation and technology markets. In three types of industries, enforcement efforts to protect product market competition are likely to encourage innovation.

\section{1. "Winner-Take-Most" or "Winner-Take-All" Markets}

Antitrust intervention to foster product market competition in "winner-take-most" or "winner-take-all" markets, including many high-tech markets, can be expected in general to benefit innovation. ${ }^{50}$ In winner-

${ }^{47}$ See Rambus Inc., 2007-1 Trade Cas. (CCH) I75,585 (2006); Dell Computer Corp, 121 F.T.C. 616 (1996) (consent order). Exclusionary conduct, involving innovation or otherwise, is particularly suspect when it is both inexpensive to undertake and lacks cognizable efficiencies. Susan A. Creighton, D. Bruce Hoffman, Thomas G. Krattenmaker \& Ernest A. Nagata, Cheap Exclusion, 72 Antitrust L.J. 975 (2005). In principle, innovation could also be promoted by challenges to another form of exclusionary conduct involving innovation competition: preemptive R\&D expenditures by dominant firms. Such expenditures benefit the dominant firm largely by discouraging rival innovation rather than by leading to ways of lowering costs or improving product performance. (Firm incentives to innovate preemptively are recognized by the fourth principle.) But the problems of proof-showing that the harm to innovation from preemption of rival innovative efforts exceeds the legitimate benefit-are likely to be insurmountable in practice unless the incumbent's innovative efforts create incompatibilities for rivals without benefiting buyers.

${ }^{48}$ Technology markets give innovators options for commercializing their new ideas through licensing or joint ventures (for example, with firms that control important complementary assets), so that the innovators have choices for profiting from their new ideas beyond creating a new business on their own. Technology markets are distinguished from innovation markets and product (goods) markets in U.S. Dep't of Justice \& Fed. Trade Comm'n, Antitrust Guidelines for the Licensing of Intellectual Property $\$ 3.2$ (1995), available at http://www.usdoj.gov/atr/public/guidelines/0558.htm. The promotion of competition in technology markets fosters innovation by increasing the reward to the innovator.

${ }^{49}$ Shane Greenstein, Market Structure and Innovation: A Brief Synopsis of ReCENT Thinking (2002), available at http://www.ftc.gov/opp/intellect/greenstein.htm.

${ }^{50}$ Antitrust cases in winner-take-most industries commonly involve challenges to horizontal mergers or allegations of exclusionary conduct by a dominant firm. See, e.g., United States v. Microsoft Corp., 253 F.3d 34 (D.C. Cir. 2004) (exclusionary conduct by dominant firm in operating system software); Intel Corp., FTC Docket No. 9288 (June 8, 1998) (Complaint), available at http://www.ftc.gov/alj/D9288/index.htm (exclusionary conduct by dominant firm in microprocessors); Catherine Fazio \& Scott Stern, Innovation Incentive, Compatibility, and Expropriation as an Antitrust Remedy: The Legacy of the Borland/ Ashton-Tate Consent Decree, 68 AnTitrust L.J. 45 (2000) (horizontal merger in relational 
take-most markets, a successful innovator can expect to capture a large market share because of such factors as intellectual property rights, scale economies in production, network effects, ${ }^{51}$ and the absence of strong buyer preferences for product variety. ${ }^{52}$ The successful innovator would reasonably continue to expect to do so if antitrust enforcement enhances post-innovation competition as well as pre-innovation competition. ${ }^{53}$ Under such circumstances, meritorious antitrust intervention to protect product market competition in winner-take-most industries is likely to enhance pre-innovation competition without making much difference to post-innovation competition. ${ }^{54}$ Any resulting disincentive to

database software); Gilbert \& Tom, supra note 42, at 55-58 (horizontal merger in gene therapy treatments); $c f$. Gilbert, supra note 10 (draft at 2-4) (documenting increased importance of innovation concerns in enforcement agency analysis of mergers). Shane Greenstein has emphasized the importance of using competition policy to encourage multiple commercial visions, even when fringe firm innovations have only modest probabilities of success. "[C]ommercial failure should not be thought of as an obvious waste of resources" because of what it can teach others working on their own innovations. Greenstein, supra note 49. Cf. Timothy F. Bresnahan \& Shane Greenstein, Technological Competition and the Structure of the Computer Industry, 47 J. Indus. Econ. 1 (1999) (describing platform competition in the computer industry over three decades).

${ }^{51}$ When a product or service exhibits network effects (or demand-side scale economies) its value to a buyer rises when some other buyer also purchases it.

${ }_{52}$ In a "winner-take-most" industry (as opposed to a "winner-take-all" industry), the successful innovator would expect to capture most, but not all, of the market. For example, if a minority of buyers have strong preferences for particular product attributes, small rivals may succeed by serving narrow niches, notwithstanding the general tendency for one seller to serve most buyers.

${ }^{53}$ Consideration of preemption incentives (the fourth principle) does not change this conclusion, even if the innovation is not drastic (decreasing the strength of the Arrow effect disincentive facing an innovating monopolist). The possibility of pre-innovation preemption by a dominant firm in a winner-take-most industry might make it more difficult for antitrust enforcers to foster innovation by encouraging greater pre-innovation product market competition but does not detract from the benefits of enhancing product market competition. Similarly, the possibility that a successful innovator in a winner-takemost industry would undertake further innovation to preempt rivals might be a reason for antitrust concern about exclusionary conduct limiting innovation in the post-innovation industry but it again does not detract from the benefits of enhancing product market competition (to implement the second principle).

${ }^{54}$ For example, incentives to innovate in winner-take-most markets are likely enhanced by antitrust enforcement against exclusionary conduct by dominant firms lacking a legitimate business justification, such as challenges to sham product improvements that create incompatibilities for rivals without benefiting buyers. Consistent with this approach, courts have found that product design decisions can constitute monopolization if they are not ways of lowering costs or improving product performance. Microsoft Corp., 253 F. 3d at 64-67; California Computer Prods., Inc. v. IBM Corp., 613 F.2d 727, 744 (9th Cir. 1979); Berkey Photo, Inc. v. Eastman Kodak Co., 603 F.2d 263, 287 n.39 (2d. Cir. 1979). Shane Greenstein has described how Microsoft's insistence in 1995 that personal computer manufacturers not alter the "first screen" had "consequences for other firms' innovative behavior by raising distribution costs to application firms," some of which undoubtedly competed with Microsoft, without affecting the incentives for the programmers at Microsoft to design a good product. Greenstein, supra note 49. Although this aspect of Microsoft's conduct was later found to support a finding of monopolization in the operat- 
dominant firm innovation from post-innovation competition would likely be small and outweighed by the improved innovation incentives facing fringe rivals. Fostering product market competition in winnertake-most industries enhances innovation incentives on the whole by, in effect, threading the needle between the second and third economic principles set forth above. ${ }^{55}$

A hypothetical example again involving Intel-not developed or intended to capture or take sides in ongoing antitrust litigation regarding that firm-may help clarify the point. Assume that microprocessors for personal computers are reasonably characterized as a winner-take-most industry. Suppose further that Intel is a dominant firm in microprocessors, and that Intel has harmed competition in a product market for current generation microprocessors by engaging in anticompetitive conduct that excludes AMD, a small rival, perhaps by raising AMD's costs or reducing AMD's access to customers. Under such circumstances, antitrust intervention to restore product market competition would promote innovation through operation of the second principle. That is, increased product market competition today would encourage both Intel and AMD to innovate to escape competition. Intel will be encouraged to innovate faster, and AMD will be less likely to prefer to live and let live or to commit to a strategy of declining to take on Intel aggressively. ${ }^{56}$ This conclusion is not undermined by the third principle, even though the antitrust relief will also promote competition in the future. That prospect will do little to discourage R\&D by Intel and AMD because the market is winner-take-most. After all, the large prize that goes to the firm that captures the market with the next generation of products remains large even if it is reduced somewhat by an antitrust decision clarifying that the successful innovator cannot employ certain exclusionary tactics in the future. Accordingly, the innovation incentives recognized by the third principle will not markedly be undermined.

This is not to say that antitrust complaints charging harms to product market competition in winner-take-all or winner-take-most industries are invariably meritorious. In any individual case, it will be important to account for procompetitive business justifications as well as potential an-

ing system market, the case did not address Greenstein's concern about harm to innovation in applications markets.

${ }^{55}$ Cf. Segal \& Whinston, supra note 37 (antitrust enforcement against a range of exclusionary and collusive practices increases aggregate incentives to innovate in models in which only potential entrants conduct $\mathrm{R} \& \mathrm{D}$, or incumbents also conduct $\mathrm{R} \& \mathrm{D}$ with a large prize to successful $\mathrm{R} \& \mathrm{D}$ (such as avoiding displacement by an entrant)).

56 See Judith Gelman \& Steven Salop, Judo Economics: Capacity Limitation and Coupon Competition, 14 BeLl J. ECON. 315 (1983) (entrant induces incumbent accommodation by committing to limited entry). 
ticompetitive harms. ${ }^{57}$ The point is simply that we should not worry that antitrust enforcement actions in such industries will systematically chill innovation. ${ }^{58}$ To the contrary, such cases are likely to promote innovation.

This analysis bears on the ongoing debate over the appropriate legal standard for identifying exclusionary acts in evaluating monopolization claims other than predatory pricing. ${ }^{59}$ In brief overview, the current dispute is between advocates of two positions. Under one view, a bad act should be identified through a reasonableness or balancing test, perhaps structured as a set of quick-look presumptions. ${ }^{60}$ According to the other view, the legal standard should instead place a thumb on the scales to make it more difficult for plaintiffs to succeed. A variety of approaches for doing so have been proposed, including the "profit-sacrifice" test, the "no economic sense" test, and the "disproportionate impact" test. ${ }^{61}$ From the perspective of fostering innovation, the previous discussion indicates that a reasonableness or balancing standard for identifying bad acts is preferable to any test that deviates from that stan-

${ }^{57}$ I do not mean to suggest that an unstructured rule of reason must invariably be applied to decide cases in preference to per se rules or structured (quick-look) inquiries under the rule of reason.

${ }^{58}$ Here I assume that the judicial system generally tends to weed out cases unsupported by the facts. The greater the probability that a meritless case would be brought and would succeed, the greater the likelihood that a dominant firm (or a would-be dominant firm) would act cautiously to avoid provoking such a lawsuit, as by lessening its innovative effort or channeling that activity away from projects with the greatest social value. If incentives to innovate are harmed by the prospect of judicial errors, that disincentive would not be related to the four economic principles emphasized in the text.

${ }^{59} \mathrm{An}$ antitrust challenge to exclusionary conduct by a dominant firm-including one that has come to dominate a "winner-take-most" market-is perhaps most naturally brought as a monopolization case under Sherman Act Section 2, 15 U.S.C. § 2. Monopolization requires proof of both monopoly power and a bad act to obtain or maintain that power. The legal standards for identifying bad acts when the exclusionary conduct does not involve price have been the subject of recent debate.

${ }^{60}$ Microsoft Corp., 253 F.3d at 58-59 (identifying bad acts through a structured reasonableness test). See Steven C. Salop, Exclusionary Conduct, Effect on Consumers, and the Flawed Profit-Sacrifice Test, 73 Antitrust L.J. 311 (2006) (defending consumer welfare test in preference to profit-sacrifice test).

${ }^{61}$ See Andrew I. Gavil, Exclusionary Distribution Strategies by Dominant Firms: Striking a Better Balance, 72 ANTITRUST L.J. 3, 52-65 (2004) (surveying range of proposed standards); see also Einer Elhauge, Defining Better Monopolization Standards, 56 Stan. L. Rev. 253, 323, 330 (2003) (recommending focus on whether conduct harmed rivals only through efficiency); A. Douglas Melamed, Exclusive Dealing Agreements and Other Exclusionary ConductAre There Unifying Principles?, 73 Antitrust L.J. 375 (2006) (defending "profit-sacrifice" test); Gregory J. Werden, Identifying Exclusionary Conduct Under Section 2: The "No Economic Sense" Test, 73 Antitrust L.J. 413 (2006) (defending "no economic sense" test); $c f$. Mark S. Popofsky, Defining Exclusionary Conduct: Section 2, the Rule of Reason, and the Unifying Principle Underlying Antitrust Rules, 73 AnTitrust L.J. 435 (2006) (surveying proposed tests and recommending different tests for different types of cases). 
dard to favor defendants when the monopolization allegation involves a winner-take-most market-the setting where monopolization cases most commonly raise concerns about innovation. ${ }^{62}$

\section{Industries Where Technological or Regulatory Developments Determine Future Competition}

Antitrust enforcement to protect product market competition can also be expected to benefit innovation in a second type of industry: one in which the extent of future product market competition is likely to be unaffected by the extent of current product market competition because of probable technological or regulatory developments. Suppose, for example, that traditional telephone service providers should reasonably expect to face future competition for many of their current services from cable and wireless providers, and possibly wireline competition from the electric company as well. Then antitrust enforcement to protect competition in the provision of telephone services in the current product markets where such future competition is likely would be expected to enhance innovation incentives for telephone companies, relative to a "but-for" world in which there is less competition among telephone service providers but the same anticipated future competition from cable and wireless. ${ }^{63}$

\footnotetext{
62 Antitrust courts have arguably adopted a rebuttable presumption that new products or processes do not harm competition so long as they confer some benefits to buyers. Consistent with this view, an innovation is unlikely to constitute a bad act in support of monopolization unless it is a sham, and a monopolist's unilateral refusal to license its intellectual property or sell its patented or copyrighted products carries with it a presumptively valid business justification for harm to consumers. Such a presumption is not inconsistent with a reasonableness standard. It is better understood as a bright-line rule (or quick-look rule) implementing the reasonableness standard when monopolization allegations involve $R \& D$ or innovation, which recognizes the social benefits of innovation and the particular difficulty of assessing the long-term benefits and harms of R\&D investments and the new products and processes they create. Cf. Richard Gilbert, Holding Innovation to an Antitrust Standard, 3 Competition PoL'y InT'L 47 (2007) (advocating presumption that innovation is procompetitive).

${ }^{63}$ In the but-for world, the telephone companies would expect to be insulated from cable and wireless competition in the near term but not in the long term. Greater competition in current telephone products would in effect speed the arrival of more intense competition, and so speed telephone company efforts to escape that competition through innovation (applying the second economic principle). Lessened near-term insulation from competition would work in the opposite direction, discouraging innovation by increasing the prospect that an innovator would face greater rivalry (applying the third principle). If the telephone companies are already developing new products and services in response to their expectation of future cable and wireless competition, the net effect of greater product competition today would most likely be to accelerate their introduction of those new products and services (the incentives captured by the second principle are likely to dominate).
} 


\section{Rapidly-Growing Industries}

Third, and for similar reasons, the prospect of rapid market growth would tend to make $\mathrm{R} \& \mathrm{D}$ investment attractive, even if rivals are also seeking to capture sales in the same industry. If the market will likely be much larger in the near future, many firms can be expected to invest in $\mathrm{R} \& \mathrm{D}$ to try to capture a share of the anticipated growth. ${ }^{64}$

While this is the most likely dynamic, an exception might arise if one firm is thought to have a lead in developing a substantially better product or production process and if its rivals expect that the leader would be able to obtain a substantial first-mover advantage in the product market (for example, from strong network effects or scale economies). Then rival R\&D might be discouraged by the prospect of future competition with the leader - that is, through the application of the third economic principle. Another exception might arise if an innovation leader would reasonably anticipate obtaining broad intellectual property protection that precludes as a practical matter a rival's ability to invent around its innovation. ${ }^{65}$ In this setting, an incumbent may be able to discourage entry through preemptive $\mathrm{R} \& \mathrm{D}$ - that is, through the application of the fourth economic principle. But these exceptions are, at most, situations in which the third or fourth economic principle might operate to limit the benefits to innovation of efforts to enhance product market competition (and so to qualify the benefits of applying the second economic principle). They might be relevant to deciding where to allocate scarce enforcement resources but they are not reasons to avoid antitrust enforcement in rapidly growing markets. ${ }^{66}$

\footnotetext{
${ }^{64}$ This point is similar to the observation in the Horizontal Merger Guidelines that an entrant's ability to capture a share of reasonably anticipated market growth makes entry more likely, by increasing the "sales opportunities" available to entrants. U.S. Dep't of Justice \& Fed. Trade Comm'n, Horizontal Merger Guidelines § 3.3 (1992, revised 1997), available at http://www.ftc.gov/bc/docs/horizmer.htm [hereinafter Merger Guidelines].

${ }^{65}$ Similarly, if an initial R\&D success confers a large advantage in undertaking further $\mathrm{R} \& \mathrm{D}$, a first-mover advantage in $\mathrm{R} \& \mathrm{D}$ might operate to discourage rival $\mathrm{R} \& \mathrm{D}$ investments.

${ }_{66}^{6}$ Again, the antitrust complaints must be meritorious. In any individual case, it will be important to account for procompetitive business justifications as well as potential anticompetitive harms. It is worth remarking on one conceivable business justification involving innovation for exclusionary conduct that allows a dominant firm to obtain or maintain a product market monopoly. That possibility arises when the firm needs a large scale of production (or substantial cumulative production, to generate low marginal costs through learning-by-doing) to make profitable a potential innovation. For example, a lemonade stand owner may wish to conduct research on a new kind of lemon press, but would not find it worthwhile to undertake the R\&D unless she could reasonably expect to use it on a large volume of lemons. (Or a telephone firm may wish to develop a new type of switch.) If the only practical way for the firm obtain the necessary scale is to obtain a dominant position in the product market before investing in $\mathrm{R} \& \mathrm{D}$, this could provide a justification for conduct that might tend to reduce product market competition (which might or might not outweigh the harm from the loss of product market competition). But
} 


\section{Protecting Product Market Competition: Types of Conduct}

An antitrust enforcement program can also promote innovation by challenging a range of practices harming product market competition. These include enforcement against "naked" horizontal agreements to fix prices or allocate customers (agreements among rivals with no plausible efficiency justification). They also include challenges to agreements among rivals to engage in conduct facilitating coordination with no plausible business justification, such as exchanges of information on future plans (when not required to make operational a legitimate joint venture) or on current transactions (beyond what is necessary to inform customers of what is available for sale). Preventing these types of collusive arrangements enhances competition in pre-innovation product markets, consistent with the second economic principle. By contrast, antitrust enforcement against such agreements is generally unlikely to implicate the third economic principle, at least if the innovation is drastic, because a firm that creates a dramatically better or cheaper product would reasonably expect its introduction to destabilize any such agreement even in the absence of enforcement. ${ }^{67}$ Under such circumstances, the post-innovation product market would likely be comparably competitive regardless of whether the pre-innovation cartel was challenged.

Challenges to horizontal mergers likely to reduce product market competition-that is, meritorious merger cases focused on current or near-term potential product market competition rather than innovation market competition-are also, in general, unlikely to reduce incentives to innovate. After all, it is hard to believe that much $\mathrm{R} \& \mathrm{D}$ is undertaken with the specific goal of eventually selling the firm to a horizontal rival. ${ }^{68}$

\footnotetext{
this justification should not be accepted if there are reasonable and practical less-restrictive alternatives. For example, the innovative lemonade firm may reasonably expect that if its R\&D succeeds, it could obtain the necessary scale through internal growth (and obtain financing from investors impressed with the cost-saving potential of its new production process). Or it may be practical for the firm to enter into input supply agreements with rival lemonade stands, by which the innovator presses lemons for the industry and sells the resulting raw juice to many lemonade stands.

${ }^{67}$ The Code of Fair Competition devised by the steel industry pursuant to the National Industrial Recovery Act during the Great Depression prohibited secret, selective price cutting and the erection of new production capacity. But it exempted from the latter ban two areas of ongoing technical progress: new electric furnaces and improvements in steelfinishing capacity. Jonathan B. Baker, Identifying Cartel Policing Under Uncertainty: The U.S. Steel Industry 1933-1939, 32 J.L. \& ECON. S47, S58 n.31 (1989). One interpretation is that the industry recognized that an agreement restricting pre-innovation product market competition would not discourage colluding firms from introducing drastic innovations.

${ }^{68}$ Start-up innovators do at times merge with established firms. A start-up innovator can choose whether to compete with established rivals-as is common in electronics-or whether instead to cooperate with them through licensing, alliance, or merger-as is common in biotechnology. See generally Gans, Hsu \& Stern, supra note 12.
} 
For horizontal merger enforcement to undermine the incentives to innovate by discouraging start-ups, the start-up would have to anticipate that its innovation would be more valuable to a horizontal rival than to an established firm with complementary product lines, and to anticipate that it would not be able commercialize its product about as well by licensing its new idea. ${ }^{69}$ In consequence, it is unlikely that firms would refrain from efforts to innovate for fear that later merger enforcement would significantly reduce the value of their new idea..$^{70}$ Moreover, the antitrust enforcement agencies routinely consider efficiencies involving both the production of current products and innovation in horizontal merger analysis, limiting the danger that merger enforcement would chill innovation. ${ }^{71}$

${ }^{69}$ The antitrust enforcement agencies evaluate patent licenses under the rule of reason, examining factors that include whether the patent holder possesses market power in the relevant market, whether the practice encourages unlawful coordination among competitors, whether the practice inhibits entry of other firms through the licensing regime's exclusivity or exclusion, and whether the practice reduces the incentive to innovate in the future. U.S. Dep't of Justice \& Fed. Trade Comm'n, Antitrust Enforcement and Intellectual Property Rights: Promoting Innovation and Competition ch. VI (2007), available at http://www.usdoj.gov/atr/public/hearings/ip/222655.pdf. In practice, antitrust law rarely objects to licensing transactions undertaken before the new idea has been commercialized, even if the licensee is the incumbent firm. For a recent economic discussion of the appropriate scope of antitrust restrictions on patent licensing, see Stephen M. Maurer \& Suzanne Scotchmer, Profit Neutrality in Licensing: The Boundary Between Antitrust Law and Patent Law, 8 Am. L. \& Econ. Rev. 476 (2006).

${ }^{70}$ Put differently, if antitrust enforcement takes away the payoff to horizontal merger, a start-up or innovator would likely continue to have the ability to merge with a firm that produces complements or to license a new idea at an early stage to a horizontal rival, because antitrust is more hospitable to these types of transactions. In consequence, innovation incentives would not markedly be reduced.

${ }^{71}$ For example, Michael Katz and Howard Shelanski raise the possibility of a market in which firms are deterred from innovating by the prospect of post-merger product market competition. (Their example concerns a market in which the third economic principle happens to dominate the second.) Under such circumstances, a merger could enhance incentives to innovate by reducing that competition, but merger review would need to trade off that social benefit against the social cost of reduced post-merger price competition. Katz \& Shelanski, supra note 1 at 66-67 (Case 3). More generally, efficiency benefits involving innovation count in favor of proposed mergers if they are merger-specific and problems of proof can be overcome. Merger Guidelines, supra note $64, \S 4$ ("Other efficiencies, such as those relating to research and development, are potentially substantial but are generally less susceptible to verification and may be the result of anticompetitive output reductions."). Mergers can generate efficiency benefits involving innovation in many ways. For example, they may help speed R\&D by allowing firms to share complementary research (e.g., if one firm has a good approach to one step of the process, the other a good approach to another step); speed the introduction of a new product by connecting a firm with promising R\&D with a rival that has a strong distribution system; increase the scale of production to make production process R\&D more profitable; create cost reductions by allowing firms to avoid duplicative $\mathrm{R} \& \mathrm{D}$; improve coordination among complementary products by facilitating the adoption of a standard interface; or speed R\&D by allowing firms to share information about whether certain approaches are dead ends. But merging firms would not be permitted to justify their transaction on the ground 


\section{E. Why Antitrust Enforcement Promotes Innovation}

As detailed above, the four economic principles relating competition and innovation suggest where to focus competition policy in order to foster innovation. In particular, an antitrust enforcement program crafted to promote innovation would attack direct reductions in innovation competition; protect product market competition in winner-takemost or winner-take-all markets; protect product market competition in markets in which probable technological or regulatory developments or rapid growth in demand largely determine the extent of future product market competition; challenge naked horizontal agreements to fix prices or allocate customers; prevent agreements among rivals to engage in conduct facilitating coordination with no plausible business justification; and challenge horizontal mergers likely to reduce product market competition.

Measured against this standard, contemporary competition policy holds up well. These areas account for the great bulk of antitrust enforcement at the federal agencies, as well of much of what goes on in the states and in private suits. ${ }^{72}$ There are other areas of antitrust enforcement, including cases challenging vertical restraints, vertical mergers, and restrictions imposed by legitimate horizontal joint ventures in industries not characterized by winner-take-most competition, likely technological or regulatory change, or rapid growth. In these remaining areas, antitrust intervention could, in theory, simultaneously enhance pre-innovation product market competition and reduce post-innovation competition, with the net effect on innovation incentives unclear. In practice, however, antitrust enforcement in these other areas is, on the whole, measured. The great majority of such conduct will not be found to harm competition under current antitrust standards, so these kind of cases in the aggregate would present little threat to innovation in the economy even if the incentives at issue in the third and fourth economic principles turned out to be particularly important in the settings for those enforcement actions. Accordingly, it is unlikely that antitrust enforcement to protect product market competition in areas outside those that would be emphasized by a policy focused on innovation would systematically affect the level of post-innovation competition reasonably anticipated by firms conducting R\&D throughout the economy.

that the profits they earn from reducing competition in the product market would enhance their ability to fund R\&D. See generally Katz \& Shelanski, supra note 1, at 49-54.

${ }^{72}$ Most federal enforcement resources go into investigation of cartels, unreasonable agreements among rivals, and mergers among rivals. Private enforcement attacks a broader array of possible violations. 


\section{CONCLUSION}

Antitrust commentators and enforcers need not be defensive about the benefits of competition policy for innovation. Today's antitrust institutions support innovation by targeting types of industries and practices where antitrust enforcement would enhance $R \& D$ incentives the most. It is time to move beyond the "Schumpeter vs. Arrow" debate and to embrace antitrust as essential for fostering innovation. The benefits of antitrust rules and enforcement extend beyond lower prices, greater output, and higher product quality; they also include increased innovation. 